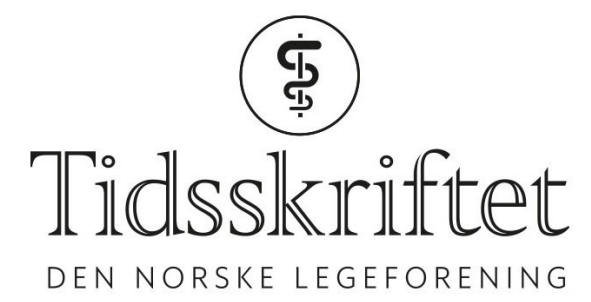

\title{
Hva vil det si å være en god leder?
}

LEDER

\section{NEZAR RAOUF}

E-post:nraouf2ooo@yahoo.se

Nezar Raouf er spesialist i indremedisin og i hjertesykdommer og avdelingssjef ved Avdeling for akuttmedisin, Sykehuset Østfold.

Forfatteren har fylt ut ICMJE-skjemaet og oppgir ingen interessekonflikter.

Legeforeningens lederpris deles ut årlig til leger som har vist god ledelse. Hva vil det egentlig si å være en god leder? Og hvordan kan vi skape gode ledere for fremtiden?

Jeg har blitt bedt om å skrive denne teksten fordi jeg ved Legeforeningens landsstyremøte ble tildelt årets lederpris. Innstillingskomiteen trakk frem forbedringsarbeid, nytenkning og kreativitet som begrunnelse for avgjørelsen. En slik anerkjennelse fra kollegaer gir grunn til ydmyk ettertanke over hva som kjennetegner en god leder. Prisen kan kanskje sees på som en bekreftelse på at tankesettet som preger min lederstil, fungerer. Her vil jeg forsøke å skissere dette tankesettet.

En leder bør ha en klar visjon med sitt lederskap og være i stand til å formidle dette til sine medarbeidere, for vedkommende kan kun lede hvis han eller hun har et team rundt seg som deler visjonen. Som avdelingssjef ved en akuttmedisinsk avdeling er jeg omgitt av en gruppe yngre ledere som har blitt delegert til å styre innenfor sine arbeidsområder. Jeg har erfart at en leders tankemåte kan være smittende og at medarbeiderne på den måten projiserer disse tankene videre. Slik generasjonskontinuitet gjenspeiler mester-svennforholdet som gjennom tidene har vært vanlig i vårt yrke og som vi aldri må miste gjennom faste rutiner og automatiserte algoritmer.

Jeg leder et akuttmottak der tilstanden kan skifte raskt mellom orden og kaos. Ofte er det en jevn flyt, men plutselig kan krevende situasjoner dukke opp. Da er panikk, men i kontrollerte former, forventet. Årvåkenhet, nærmest til det paranoide, bør det også være rom for. Kreativitet og fleksibilitet kan være avgjørende når det er behov for å avvike fra standardrutiner. Jeg mener kjernen i vår medisinske profesjon er at vi nærmest daglig tvinges ut av komfortsonen. Kartet stemmer ikke med terrenget og vi kan ikke forutse hva som kommer. Gode rutiner og prosedyrer kan være med på å begrense kaoset i krevende situasjoner, men det er ikke tilstrekkelig. Minst like viktig er det å vite når man skal avvike fra rutinen. Man kan planlegge, trene, vurdere og revurdere i det uendelige, men det kan ikke erstatte en fleksibel tankegang, der man $t ø r$ å avvike fra normen når situasjonen krever det. Dette gjelder kanskje spesielt i akuttmottak, der ting skjer fort og situasjoner skifter raskt. I legeyrket kan improvisasjon av og til oppfattes som en risikosport, og det er en hårfin balanse mellom det å gi et medisinsk team spillerom og samtidig ikke oppmuntre til en «cowboykultur». For å gi rom for optimal mestring av slike situasjoner er det avgjørende at medarbeiderne kjenner sin leders tankegang og aksept for fleksibilitet. Det er også viktig 
at man som leder har forståelse av hva de ulike arbeidsoppgavene innebærer, derfor bør kliniske ledere velges fra samme profesjon som dem de skal lede. Det er lettere å oppnå respekt og få gehør for sine avgjørelser når man leder sine «egne».

Nærhet til dem man skal lede, er avgjørende. Det samme er nærhet til faget

Nærhet til dem man skal lede, er avgjørende. Det samme er nærhet til faget, til vitenskapen vi alle er dedikert til. Å miste det vitenskapelige engasjementet, enten fordi man distraheres av daglige kriser og administrative oppgaver eller fordi man setter forskning lavere på prioriteringslisten av hensyn til budsjettet, kan få enorme konsekvenser. En medisinsk leder bør alltid kjempe for vitenskap og forskning som kjerneverdier og være talsmann for disse.

Administrasjon er nært knyttet til ledelse, og administrative evner er en kunst i seg selv, et eget mål for lederskap. Men altfor ofte blir administrasjon klumpet sammen med andre oppgaver. Når det skjer, blir medisinsk leder fanget i en labyrint av regelverk og papirarbeid og dermed isolert fra oppgaver og relasjoner som er avgjørende for å lede et bredere medisinsk team. I det øyeblikket lederen mister bakkekontakten og kontakten med de man skal lede, er slaget tapt.

Helsevesenet står overfor en fremtid med mange utfordringer, og gode ledere er viktigere enn noen gang. Derfor bør sykehusene prioritere å få frem unge ledertalenter og legge til rette for at de kan få utvikle seg til å bli gode ledere. En viktig egenskap hos en god leder er nettopp å gjenkjenne spirende ledertalenter og kunne delegere ansvarsområder til disse, gjerne på et tidlig stadium. Vi er ikke klare til å møte morgendagens utfordringer før neste generasjons ledere er klare til å overta fakkelen.

Publisert: 2. oktober 2019. Tidsskr Nor Legeforen. DOI: 10.4045/tidsskr.19.0505

(C) Tidsskrift for Den norske legeforening 2020. Lastet ned fra tidsskriftet.no 